\title{
Los menores en el entorno digital. Usos, influencias, responsabilidades
}

\author{
Minors in the digital environment. Uses, influences, and responsibilities
}

\section{Coordinadores científicos / Scientific coordinators}

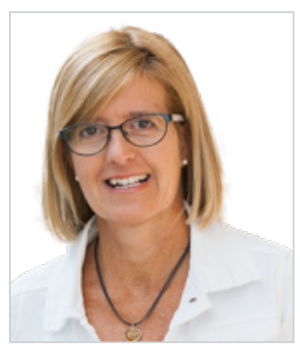

María del Carmen García Galera. Doctora en Ciencias de la Información y Profesora Titular de la Facultad de Ciencias de la Comunicación de la Universidad Rey Juan Carlos de Madrid. Entre sus líneas de investigación se encuentra el estudio de los efectos de la violencia de los medios de comunicación en la audiencia, y los usos y responsabilidades ante las nuevas formas de comunicación social digital. Desde 2008 viene desempeñando de manera ininterrumpida puestos de gestión unipersonal, siendo en la actualidad Coordinadora del Grado de Publicidad y Relaciones Públicas de la Universidad Rey Juan Carlos.

Doctor of Information Sciences and Associate Professor of the Faculty of Communication Sciences at Universidad Rey Juan Carlos in Madrid. Her lines of research include the study of the effects of media violence on the audience, as well as the uses and responsibilities of new forms of digital social communication. Since 2008, she has been working continuously in the management of sole proprietorships, and is currently Coordinator of the Advertising and Public Relations Degree at Rey Juan Carlos University.

Universidad Rey Juan Carlos, Madrid, España

carmen.garcia@urjc.es

ORCID: 0000-0001-6211-2700

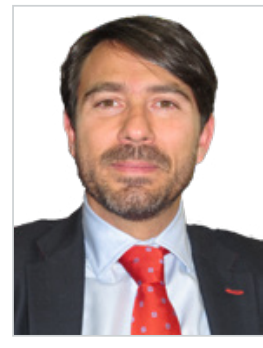

Leopoldo Abad Alcalá. Catedrático de Derecho Constitucional de la Universidad CEU San Pablo. Doctor en Ciencias de la Información por la Universidad Complutense de Madrid (UCM) y doctor en Derecho por la Universidad CEU San Pablo. Ha sido investigador Principal (IP) de varios proyectos de investigación en el Plan Nacional de I+D+i sobre Brecha digital y personas mayores Es autor de más de 40 publicaciones sobre diversos aspectos de la regulación de la actividad comunicativa y ha sido profesor invitado en universidad europeas, estadounidenses e iberoamericanas. Fue Vicerrector de Alumnos de la Universidad CEU San Pablo.

Chair of Constitutional Law at CEU San Pablo University of Madrid. Doctor in Information Sciences from the Universidad Complutense de Madrid (UCM) and he also holds a PhD in Law from Universidad CEU San Pablo. He has been the Principal Investigator (PI) of several research projects under the National R\&D\&i Plan concerning the digital divide and the elderly. He is the author of more than 40 publications on various aspects of communication regulation, and has been a guest lecturer at European, American and Latin American universities. He was Vice Rector of Students at Universidad CEU San Pablo.

Universidad CEU San Pablo, Madrid, España

abad.fhm@ceu.es

ORCID: 0000-0002-4194-6404

Cómo citar este artículo:

García Galera, M. C.; Abad Alcalá, L. (2019): Los menores en el entorno digital. Usos, influencias, responsabilidades. [Presentación de monográfico]. Doxa Comunicación, 28, pp. 173-178.

https://doi.org/10.31921/doxacom.n28a09 


\section{Presentación}

El impacto de las Tecnologías de la Información y la Comunicación (TIC) en la sociedad contemporánea ha desencadenado un repertorio de oportunidades y amenazas que han devenido en elementos constitutivos de la cultura digital. Así lo recogíamos en la presentación del I Congreso Internacional sobre Vulnerabilidad y Cultura Digital (Universidad CEU San Pablo, Madrid, 18 y 19 de octubre de 2018), donde académicos, investigadores, estudiantes y profesionales interesados en este tema compartieron sus estudios, puntos de vista y experiencias en un contexto académico de alto nivel científico.

Este Congreso se enmarca en las actividades desarrolladas por el Programa de Actividades sobre Vulnerabilidad Digital (PROVULDIG) (Ref.: S2015/HUM-3434), proyecto financiado por la Dirección General de Universidades de la Consejería de Educación, Cultura y Deportes de la Comunidad de Madrid y el Fondo Social Europeo, que despliega un conjunto de acciones institucionales, divulgativas y de investigación llevadas a cabo por un consorcio de cinco grupos de investigación consolidados en las Universidades madrileñas CEU San Pablo, Rey Juan Carlos y Complutense de Madrid (CES Villanueva).

Este consorcio está configurado como una red de investigadores interesados en estudiar las amenazas y retos que Internet representa para diversos colectivos sociales especialmente vulnerables, como los niños, los adolescentes, los jóvenes y la tercera edad.

Como corolario a este foro de discusión, debate e intercambio académico que fue el citado Congreso, ve la luz este monográfico titulado "Los menores en el entorno digital. Usos, influencias, responsabilidades”. Los artículos que lo integran, así como algunos manuscritos incluidos

\section{Presentation}

The impact of Information and Communication Technologies (ICT) on contemporary society has triggered a range of opportunities and that have become essential elements of digital culture. This was stated in the presentation of the 1st International Congress on Vulnerability and Digital Culture (I Congreso Internacional sobre Vulnerabilidad y Cultura Digital, Universidad CEU San Pablo, Madrid, 18 and 19 October 2018), where academics, researchers, students and professionals interested in this subject shared their research, points of view and experiences in an academic context of high scientific standards.

The Congress was part of the activities developed by the Program of Activities on Digital Vulnerability (Programa de Actividades sobre Vulnerabilidad Digital) -PROVULDIG(Ref: S2015/HUM-3434), a project funded by the Directorate General of Universities, Department of Education, Culture and Sports of the government of the Autonomous Region of Madrid and the European Social Fund. This program has been implementing a set of institutional, disseminative and research actions carried out by a consortium of five consolidated research groups from universities in Madrid, including CEU San Pablo, Rey Juan Carlos, and Complutense de Madrid (Centro Universitario Villanueva (CES) Villanueva, Madrid).

This consortium is organised as a network of researchers interested in studying the threats and challenges of the Internet for various especially vulnerable social groups, such as children, adolescents, young people and the elderly.

This monograph has become available as a result of the aforementioned Congress, which was a forum for discussion, debate and academic exchange. The work is entitled "Children in the digital environment; uses, influences, responsibilities" (Los menores en el entorno digital. Usos, influencias, responsibildades). The articles of which this monograph 
en la sección Miscelánea de este mismo número, se presentaron originalmente en el Congreso y, tras un riguroso proceso de selección, han sido elegidos entre los más de 100 trabajos recibidos.

El entorno digital ha dejado de ser algo novedoso para convertirse en parte de nuestras vidas cotidianas. Alguien puede imaginarse un día sin ver televisión, por ejemplo, pero difícilmente se imagina un día sin estar conectado digitalmente con su entorno (un día sin WhatsApp, un día sin revisar el correo electrónico). Pero no es algo exclusivo de la vida adulta; los menores, desde su infancia, viven rodeados de pantallas digitales, conviven en un ecosistema digital en el que se aprende, en un principio, por imitación; también por intuición, aunque al final por la propia experiencia.

Una vez más, y desde este ámbito académico, hay que hacer una llamada en pos de la alfabetización mediática en un contexto cada vez más complejo, en el que padres y educadores deben prestar una especial atención al uso que los menores a su cargo hacen de las tecnologías digitales y de sus contenidos. No es nada nuevo hablar de la influencia de los medios de comunicación en la parte más vulnerable de la sociedad, como pueden ser los menores, ante la falta de capacidad crítica y analítica propias de su edad. A principios del siglo XX, fue el cine el que preocupaba en exceso a los investigadores por la influencia "mágica" que esa enorme pantalla y sus imágenes en movimiento podrían producir en su audiencia.

Avanzando en el tiempo, muchos han sido los estudios publicados sobre los efectos -positivos y negativos- que la televisión podría ejercer en la infancia, en sus comportamientos, en su forma de enfrentarse al mundo real y en su aprendizaje sobre la realidad y la ficción. Pero el entorno digital se ha planteado como algo diferente a los medios tradicionales. La interacción entre emisor y recep- is composed, as well as some manuscripts included in the miscellaneous section of this same issue, were originally presented at the Congress, and after a rigorous selection process, they have been chosen from more than 100 papers received.

The digital environment is no longer something new and has become part of our daily lives. As an example, anyone can imagine a day without watching TV, but hardly anyone can imagine a day without being digitally connected to their environment (a day without WhatsApp, or a day without checking email). However, this is not something exclusive to adult life; minors, from the time they are children, are part of the digital ecosystem in which they learn initially by imitation, also by intuition, but ultimately from their own experience. Once again, in this academic area, it is necessary to launch a campaign in favour of media literacy within an increasingly complex setting in which parents and educators must pay special attention to the use of digital technology and its content by minors under their guardianship. By no means is it a novelty to talk about the influence of the media on the most vulnerable sector of society, which may be minors, when faced with an absence of critical and analytical reasoning capability inherent in their age. At the beginning of the twentieth century, it was the cinema that excessively concerned researchers to a great extent due to the "magical" influence that the big screen and its moving images could have on its audience.

Since that time, many studies have been published on the effects -both positive and negative- that television might have on children, on their behaviour, on their way of facing the real world, and on their ability to learn what is real and what is fiction. However, the digital environment has been approached as something different from the traditional media. The interaction between transmitter and receiver and how the latter assumes the role of media prosumer, as well as the immediacy in the flow of information/communication, have become some of the characteristic features of our time, 
tor, y cómo este asume el rol de prosumidor mediático, así como la inmediatez en el flujo de la información/comunicación, se convierten en algunos de los elementos característicos de nuestro tiempo, y tiene, lógicamente, consecuencias en las conductas de los individuos digitales.

Es en este contexto de aproximación al entorno digital y sus consecuencias en el que se desarrolla el trabajo titulado "La convergencia mediática, los riesgos y el daño online que encuentran los menores", de los profesores Garitonaindia, Karrera y Larrañaga, de la Universidad del País Vasco. El artículo presenta los resultados de una encuesta realizada a 500 menores españoles usuarios de Internet de entre 9 y 16 años, y a sus progenitores. Uno de los principales hallazgos de este proyecto es que las experiencias de riesgo online no conducen necesariamente al daño, tal y como indicaron los propios menores.

En esta misma línea, otro artículo de interés es el titulado "Estado de la cuestión sobre la sexualización infantil en el entorno digital y propuestas de alfabetización mediática”, de los profesores Llovet Rodríguez (UCM), Díaz-Bustamante Ventisca (UIC) y Méndiz Noguero (UIC). Ante la llamada de reguladores, padres e investigadores para proteger los derechos de la infancia, se plantean propuestas que favorezcan el conocimiento de la sociedad acerca de los factores y consecuencias de la sexualización infantil. Una línea de investigación muy parecida se desarrolla en los dos siguientes artículos. El primero de ellos, "El ciberacoso sexual y/o sexista contra las adolescentes. Nuevas versiones online de la opresión patriarcal de las sexualidades y corporalidades femeninas", de las profesoras Linares Bahillo, Royo Prieto y Silvestre Cabrera, de la Universidad de Deusto, aborda el ciberacoso sexual y/o sexista que sufren las chicas de la Comunidad Autónoma del País Vasco, aplicando una metodología cualitativa. and imply, logically, consequences for the behaviour of digital individuals.

In this context of approaching the digital environment and its consequences, the work entitled "Media convergence, risks and harm to children online" (originally, La convergencia mediática y los riesgos online que encuentran los menores), by professors Garitonaindia, Karrera and Larrañaga of the University of the Basque Country (Universidad del País Vasco), has been developed. The article presents the results of a survey carried out with 500 Spanish minors between 9 and 16 years of age, and with their parents as well. One of the main findings of this project has been that online risk experiences do not necessarily lead to harm, as indicated by the children themselves.

Along the same lines, another article of interest is entitled "State of the issue of child sexualisation in the digital environment and media literacy proposals" (originally, Estado de la cuestión sobre la sexualización infantil en el entorno digital y propuestas de alfabetización mediática), by professors Llovet Rodríguez (Universidad Complutense de Madrid-UCM), Díaz-Bustamante Ventisca (Universitat Internacional de Catalunya (UIC) and Méndiz Noguero (UIC). Faced with a call by regulators, parents and researchers to protect children's rights, proposals to promote society's knowledge of the factors and consequences of child sexualisation have been suggested. A very similar line of research has been developed with the following two articles. The first is entitled "Sexual and sexist cyber-harassment towards young girls. New online versions of patriarchal oppression of female sexuality and corporality" (originally, El ciberacoso sexual y/o sexista contra las adolescentes. Nuevas versiones online de la opresión patriarcal de las sexualidades y corporalidades femeninas), by professors Linares Bahillo, Royo Prieto and Silvestre Cabrera, from the University of Deusto. The article tackles the sexual and/or sexist cyberbullying suffered by girls from the Basque Autonomous Region, applying a qualitative methodology. 
El segundo de los artículos, titulado "Deontología periodística en materia de violencias contra las mujeres. ¿Quién elabora los documentos? Un estudio longitudinal desagregado por sexo sobre la autoría”, de las investigadoras Edo Ibáñez (CEU Cardenal Herrera) y Zurbano Berenguer (Centro Universitario EUSA) estudia la autoría de la producción deontológica en materia de violencia contra las mujeres y medios en los contextos español y latinoamericano, desde 1999 hasta 2018, a partir de una muestra de 58 códigos. Las autoras analizan la autoría específica atendiendo a la variable de género para conocer el grado de implicación de mujeres y hombres, y detectar si existe relación entre el sexo de los autores de los códigos y el nivel de compromiso de estos.

Por último, el trabajo de las profesoras García Orta, García Prieto y Suárez Romero, de la Universidad de Sevilla, titulado "Nuevos hábitos de consumo audiovisual en menores: aproximación a su análisis mediante encuestas", plantea otra temática, muy actual en estos momentos, como es el acceso de los menores al consumo de contenidos no lineales a través de plataformas online. Los resultados permiten conocer algunos datos descriptivos de esta realidad y confirmar el papel de prosumidor de contenidos de los más jóvenes.

Se trata, en definitiva, de una reflexión académica y científica que aborda uno de los principales retos de las sociedades contemporáneas: la vulnerabilidad digital. Vulnerabilidad que se manifiesta de diversas formas y que afecta a diferentes públicos, especialmente a aquellos que no poseen las herramientas necesarias para afrontar la complejidad del mundo digital. Estos públicos están formados por los menores y los adolescentes, las personas mayores, los grupos desfavorecidos cultural y económicamente, pero también los que sufren discriminación digi-
The second article, entitled "Journalistic deontology on violence against women. Who produces the documents? A longitudinal disaggregated study by sex on authorships" (originally, Deontología periodística en materia de violencia contra las mujeres. ¿Quién elabora los documentos? Un estudio longitudinal desagregado por sexo sobre la autoría), by researchers Edo Ibáñez (CEU Cardenal Herrera) and Zurbano Berenguer (Centro Universitario EUSA) studies the authorship of deontological writings on violence against women and the media in Spanish and Latin American contexts, from 1999 to 2018, based on a sample of 58 codes. The authors analyse the specific authorship according to the gender variable in order to gain knowledge regarding the degree of involvement of women and men, and to detect if there is a relationship between the gender of the authors of the codes and their level of commitment.

Finally, the work of Professors García Orta, García Prieto and Suárez Romero, from the University of Seville, entitled "New audiovisual consumption habits among minors: approximation through the analysis of survey data" (originally, Nuevos hábitos de consumo audiovisual en menores: aproximación a su análisis mediate encuestas), raises another issue that is highly current at this time, which is access by minors and consumption of non-linear content through online platforms. The results allow us to gain knowledge about a certain amount of descriptive data regarding this reality and confirm the role of content prosumer played by the youngest minors.

In short, this is an academic and scientific reflection that tackles one of the main challenges of contemporary societies: digital vulnerability. This vulnerability manifests itself in different ways and affects different sectors of the public, especially those who do not have the necessary tools to face the complexity of the digital world. These public sectors are not only comprised of minors and adolescents, the elderly, and groups that are culturally and economically disadvantaged, 
Minors in the digital environment. Uses, influences, and responsibilities

tal por razones sexuales o geográficas, con el mundo rural como paradigma de ello.

Estamos, por tanto, ante un aporte necesario, útil y oportuno en un entorno social cambiante, cuyo dinamismo desbocado descuelga a quienes no tienen la capacidad de avanzar a dicho ritmo, generando graves problemas para los públicos vulnerables. Todo ello debido a una inmersión excesiva repleta de confianza en los jóvenes y adolescentes o en brechas digitales para colectivos marginados por el avance tecnológico.

En resumen, este monográfico propone una reflexión sobre las complejas relaciones entre los jóvenes y los adolescentes con la tecnología, aportando nuevas ideas fruto de la investigación científica en este campo, y ofreciendo nuevas aproximaciones a tan compleja realidad social. but also those who suffer digital discrimination for sexual or geographical reasons, an example of which is rural areas.

Therefore, we are faced with a contribution that is necessary, useful and timely in a changing social environment, but its unbridled dynamism is undermining those who do not have the ability to move forward at the same rhythm, which is creating serious problems for vulnerable sectors of the public. All of this is due to inordinate trust in excessive immersion by young people and adolescents, and in the digital divide for groups that are relegated to the fringes, or marginalized, by technological progress.

In summary, this Monograph proposes a reflection on the complex relationship that young people and adolescents have with technology, offering new ideas resulting from scientific research in this field, and providing new approaches to a social reality that is highly complex. 